\title{
Population dynamics of the venerid bivalve Tawera gayi (Hupé, 1854) in the Ushuaia Bay, Beagle Channel
}

\author{
By B. J. Lomovasky ${ }^{1}$, T. Brey ${ }^{2}$ and E. Morriconi ${ }^{1}$ \\ ${ }^{1}$ Austral Centre of Scientific Research (CADIC-CONICET), Ushuaia, Tierra del Fuego, Argentina; ${ }^{2}$ Alfred Wegener Institute for \\ Polar and Marine Research, Bremerhaven, Germany
}

\section{Summary}

Growth, productivity and potential for exploitation of the clam Tawera gayi from shallow waters $(3-5 \mathrm{~m})$ of Ushuaia Bay, Beagle Channel were investigated. Mean abundance and biomass in the study area were $1091 \pm 737$ ind. $\mathrm{m}^{-2}$ and 901.83 g SFWM m$^{-2}$ (shell-free wet mass), respectively. Individual growth was described best by the von Bertalanffy growth model with the parameter values $H_{\infty}=28.03 \mathrm{~mm}$, $K=0.288$ year $^{-1}, t_{0}=-0.34\left(r^{2}=0.83\right)$. Annual production of the population was estimated to be $120.45 \mathrm{~g}$ SFWM m ${ }^{-2}$ year $^{-1}$, corresponding to a production-to-biomass ratio $(P / B)$ of 0.134 year $^{-1}$. The single negative exponential mortality model does not fit the population mortality pattern, but predation by gastropods (Xymenopsis muriciformis, Trophon geversianus, Natica sp.) appears to be the major cause of mortality. These highly mobile predators together with the comparatively slow growth and low turnover of $T$. gayi in Ushuaia Bay limit its potential for sustainable commercial exploitation.

\section{Introduction}

The littoral South American venerid Tawera gayi (Hupé, $1854)$ is found from the Beagle Channel $\left(54^{\circ} 50^{\prime} \mathrm{S}\right)$ to $33^{\circ} \mathrm{S}$ along the Pacific coast (Soot-Ryen, 1959; Dell, 1964), and to the province of Buenos Aires $\left(36^{\circ} \mathrm{S}\right)$ along the Atlantic coast (Carcelles, 1944, 1950). Tawera gayi is commercially exploited in some regions of Chile (Osorio et al., 1979; Urban and Tesch, 1996), albeit this fishery is not under management and only one study on population dynamics (Urban and Tesch, 1996) has been carried out. There is only some limited artisanal fishery on $T$. gayi along the Argentinean coast, but a few scientific investigations have been carried out: reproduction was studied in Punta Loma, $42^{\circ} 47^{\prime} \mathrm{S}$ (Schuldt, 1975), and age and growth in Golondrina Bay, $54^{\circ} 49^{\prime}$ S, Beagle Channel (Isla and Gordillo, 1996). Reproductive biology and energetics of the population from Ushuaia Bay (Beagle Channel) are currently under investigation (E. Morriconi, pers. comm.).

At present, the Beagle Channel population of T. gayi is subject to a low level artisanal fishery for personal consumption only. Therefore, we have an opportunity to carry out a baseline study of population dynamics, which will facilitate adequate stock management during potential future commercial exploitation.

\section{Material and methods \\ Sampling}

Monthly samples of the hard clams T. gayi $(\mathrm{n}=4118$ specimens) were collected in Ushuaia Bay $\left(54^{\circ} 50^{\prime} 18^{\prime \prime} \mathrm{S}\right.$, $68^{\circ} 16^{\prime} 25^{\prime \prime} \mathrm{W}$ ), Beagle Channel (Fig. 1) by SCUBA diving in an area about $400 \times 200 \mathrm{~m}$ at $3-5 \mathrm{~m}$ water depth between August 2001 and July 2002. Each month four randomly selected cores of $30 \times 30 \mathrm{~cm}$ surface area and $15 \mathrm{~cm}$ depth were dug out. Specimens were sorted from the unsieved content of the cores. During the study period the monthly mean seawater temperature ranged between $8.2^{\circ} \mathrm{C}$ in summer and $3.4^{\circ} \mathrm{C}$ in winter (Fig. 2. C. Schroeder, unpubl. data).

In all individuals collected we measured shell height $(\mathrm{H}$, umbo to the ventral margin), length ( $\mathrm{L}$, anterior-posterior axis) and width $(\mathrm{W})$ (precision $\pm 0.1 \mathrm{~mm}$ ), and determined total mass (TM), shell mass (SM) and shell-free wet mass $(\mathrm{SFWM})$ (precision $\pm 0.01 \mathrm{~g}$ ).

For size-mass relationships,

$M=a H^{b}$

linear regression analysis was carried out with the logtransformed data, where $M$ is the mass, $a$ is the intercept and $b$ is the slope.

\section{Growth}

Individual age was inferred from shell growth bands of 285 specimens randomly selected from all 4118 individuals collected during the 12-month sample period. Each left valve was sectioned along the axis of maximum growth in height $(\mathrm{H})$ and the cross-sections were polished on lapidary wheels using grits of $180,400,600$ and 1200 grade. Polished shell cuts were examined by stereomicroscope using reflecting light. Acetate peels were made of polished and etched sections from valves embedded in epoxy resin to confirm the pattern found (Rhoads and Lutz, 1980).

A mark-recapture field experiment was carried out to validate the growth pattern found. A group of 96 animals of different size $(20-30 \mathrm{~mm} \mathrm{H})$ were collected, measured and marked on the surface of the periostracum. Each animal was returned to the subtidal area and allowed to bury in an individual cage consisting of a metal tube $20 \mathrm{~cm} \varnothing \times 20 \mathrm{~cm}$ height with perforated walls to permit horizontal water flow through the cage. After 1 year the animals were recovered and annual growth lines were examined as described above. 


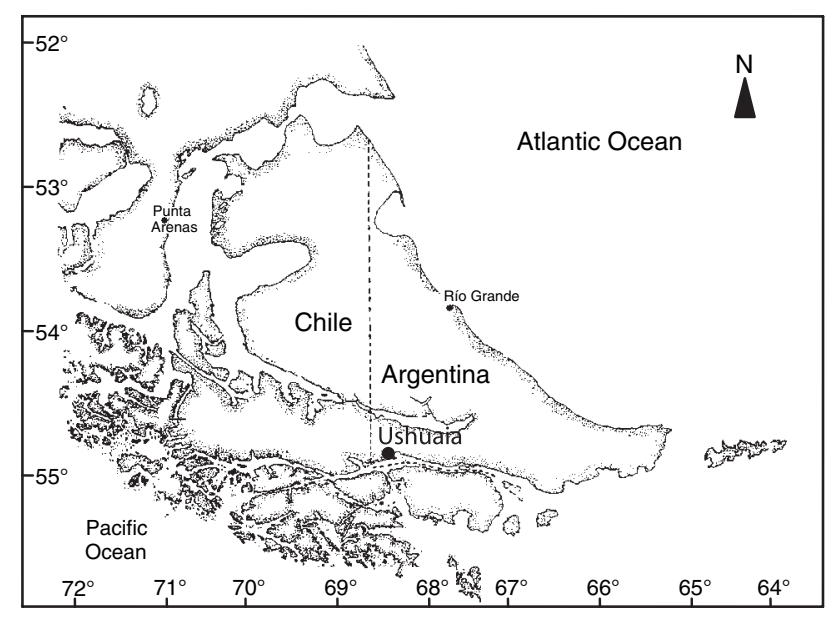

Fig. 1. Sampling site in Ushuaia Bay, Beagle Channel, Argentina, South America

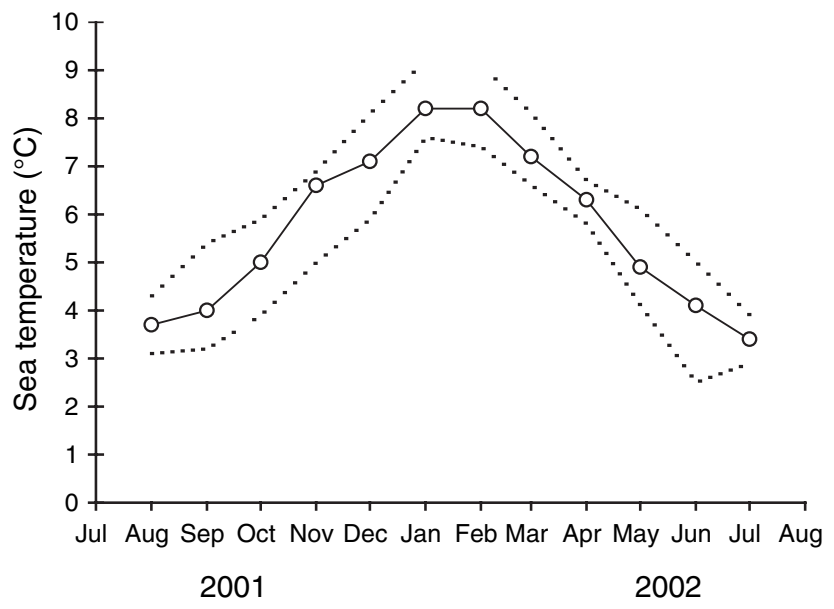

Fig. 2. Monthly mean seawater temperature with maximum and minimum values (dotted lines) in Ushuaia Bay between August 2001 and July 2002

To confirm during which season translucent and opaque bands (Jones et al., 1990) were formed, the stage of terminal growth in cross-section shells was identified within either the translucent (narrow dark) band or the opaque (wide white) band (see Arnold et al., 1998). Twenty specimens per month were analysed and monthly growth stage data were pooled into seasonal groups.

The number of annual bands and the corresponding height were recorded as age-height data. To describe growth, the von Bertalanffy growth model was used

$H_{t}=H_{\infty}\left(1-\mathrm{e}^{-k\left(t-t_{0}\right)}\right)[\mathrm{mm}$, year $]$

where, $H_{\infty}$ is asymptotic height, $K$ is the growth constant, $t$ is age and $t_{0}$ is age at zero height. The non-linear iterative Newton algorithm was used to fit the model to the data.

\section{Production}

Somatic production was calculated by the mass-specific growth rate method (Crisp, 1984; Brey, 2001) from the size-frequency distribution obtained from all pooled samples, the von Bertalanffy growth function and the size-mass relation:

$$
P=\Sigma N_{i} M_{i} G_{i}\left[\mathrm{~g} \mathrm{SFWM} \mathrm{m} \mathrm{m}^{-2} \text { year }^{-1}\right]
$$

$N_{i}$ and $M_{i}$ are the average number of animals $\left(\mathrm{N} \mathrm{m}^{-2}\right)$ and mean individual body mass in size class $i$, and $G_{i}$ is the massspecific growth rate:

$G_{i}=b K\left(\left(H_{\infty} / H_{i}\right)-1\right)\left[\right.$ year $\left.^{-1}\right]$

where, $b$ is the exponent of the size-mass relation, $K, H_{\infty}$ are parameters of the von Bertalanffy function, and $H_{i}$ is the mean size in class $i$.

Production-to-biomass ratio $(P / B)$ was computed by dividing $P$ by the biomass $B$ of the size-frequency sample.

\section{Mortality}

Total mortality rate $Z$ was estimated from the overall sizefrequency distribution and the von Bertalanffy growth function parameters by a size-converted catch curve (Pauly, 1984a,b):

$$
N_{i} / \Delta t_{i}=N_{0} \mathrm{e}^{-Z t_{i}}
$$

where, $N_{i}$ is the number of individuals in size class $i, \Delta t_{i}$ is the time required to grow through this size class and $t_{i}$ is the relative age in the mid-size of class $i$. Total mortality $Z$ is computed by the linear regression:

$\ln \left(N_{i} / \Delta t_{i}\right)=a+b t_{i} ; Z=-b$

\section{Results}

Significant exponential size-mass relationships between whole animal TM, SM, SFWM as dependent variables and $\mathrm{H}$ as the independent variable were found (Table 1).

\section{Growth}

Under reflecting light, polished shell cuts showed a pattern of alternating broad opaque and narrow translucent bands, which were also confirmed by acetate peels (Fig. 3). In general, the translucent bands showed a pink to purple colour, similar to the internal part of the shell.

Regarding the mark-recapture field experiment, only 10 animals $(10.4 \%)$ were recovered alive. A further $18(18.8 \%)$ were recaptured dead; all of them had gastropod drill holes in their shells. Analysis of the surviving specimens confirmed that one translucent growth band and one opaque growth band were formed each year. Seasonal growth terminal stage data (Table 2) showed that the translucent band was formed during autumn/winter (higher percentage of specimens forming translucent band), i. e. seasons with lowest sea temperature, and the opaque band was formed during spring/summer.

Table 1

Morphometric relations in Tawera gayi from Ushuaia Bay, Beagle Channel as described by linear regression $Y=a+b \mathrm{X}$

\begin{tabular}{llclll}
\hline $\begin{array}{l}\text { Dependent } \\
\text { variable } Y\end{array}$ & $\begin{array}{l}\text { Independent } \\
\text { variable } X\end{array}$ & $a$ & $b$ & $r^{2}$ & $\mathrm{n}$ \\
\hline $\mathrm{L}$ & $\mathrm{H}$ & 0.502 & 1.2056 & 0.99 & 4118 \\
$\log (\mathrm{TM})$ & $\log (\mathrm{H})$ & -3.6201 & 3.2428 & 0.99 & 1913 \\
$\log (\mathrm{SM})$ & $\log (\mathrm{H})$ & -3.4819 & 2.9965 & 0.99 & 1723 \\
$\log (\mathrm{SFWM})$ & $\log (\mathrm{H})$ & -4.3728 & 3.3751 & 0.96 & 1723 \\
\hline
\end{tabular}

L, shell length; H, shell height; TM, total body mass; SM, shell mass; SFWM, shell-free wet mass. 

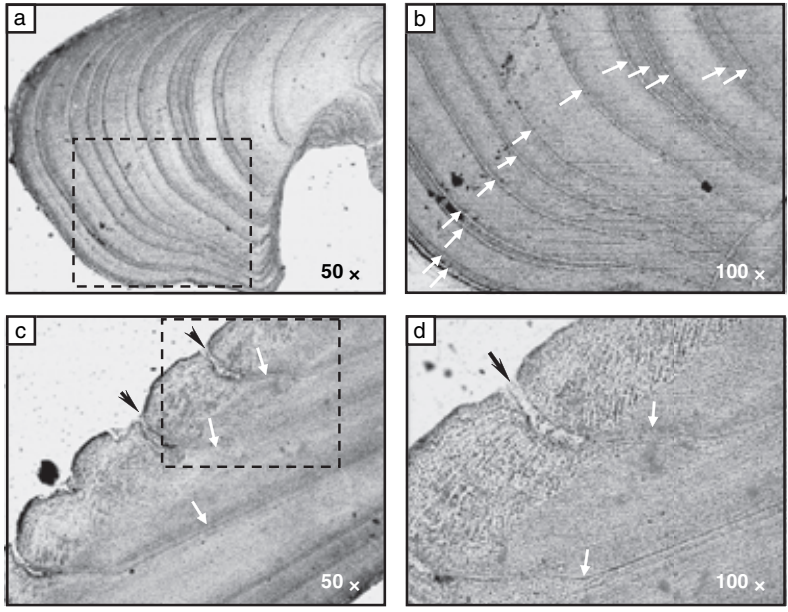

Fig. 3. Photomicrographs of acetate peel replicates of shell sections of Tawera gayi. (a and b) Umbo section showed alternating narrow translucent (white arrows) and broad opaque bands; (c and d) body shell section showed growth bands and shell breaks (black arrows) caused by low temperature and/or food

Table 2

Seasonal change in the percentage of animals in translucent growth stage, i.e. displaying a translucent growth band at the shell edge

Percentage of

animals in translucent

Season (month)

growth stage

Winter (July, August, September)

Summer (January, February March) $\quad 33.08$

Fall (April, May, June)

33.08
68.33

Shells were sectioned from the umbo to the ventral margin (axis of maximum growth) and terminal bands were examined by stereomicroscope using reflecting light.

Hence, individual age corresponds to the number of shell growth bands.

The 285 size-at-age data obtained from internal ring readings were fitted best by the von Bertalanffy growth function (Fig. 4):

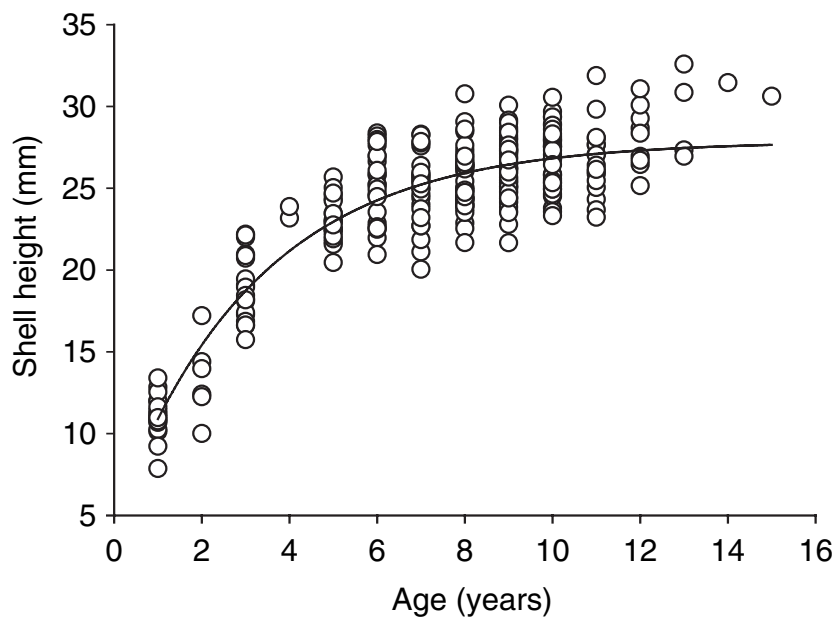

Fig. 4. Von Bertalanffy growth curve of Tawera gayi based on internal rings reading of 285 specimens. $H_{\mathrm{t}}=28.03 \mathrm{~mm}\left(1-\mathrm{e}^{-0.288(t+0.34)}\right)$; $r^{2}=0.83$
$H_{t}=28.03 \mathrm{~mm}\left(1-\mathrm{e}^{-0.288(t+0.34)}\right) ; \mathrm{n}=285 ; r^{2}=0.83$

The clams can reach a maximum age of 15 years.

Mean density was $1091 \pm 737$ ind. $\mathrm{m}^{-2}$. The annual shell height frequency data showed a peak at $2-6 \mathrm{~mm}$ and another peak at 23-28 mm (Fig. 5). A distinct peak of specimens smaller than $12 \mathrm{~mm}$ height occurred between December and March with smaller pulses the rest of the year (Fig. 6).

\section{Production}

Individual production of total soft tissues peaked at $19.5 \mathrm{~mm}$ shell height (0.42 g SFWM ind. ${ }^{-1}$ year $^{-1}$, Fig. 7), whereas SM production was highest at $18.25 \mathrm{~mm}$ shell height $(0.96 \mathrm{~g}$ SM ind. ${ }^{-1}$ year $^{-1}$ ).

Annual production of the population was $120.45 \mathrm{~g}$ SFWM m ${ }^{-2}$ year $^{-1}$, corresponding to an annual $P / B$ ratio of 0.134 year $^{-1}$ (mean biomass, $B=901.83 \mathrm{~g} \mathrm{SFWM} \mathrm{m}^{-2}$ ). Specimens between 21.5 and $28 \mathrm{~mm}$ shell height contributed most to population production (Fig. 5)

\section{Mortality}

The poor fit of the single negative exponential mortality model to the population data (Fig. 8) indicated that the mortality rate $Z$ changes with age. Hence, an overall value representative for

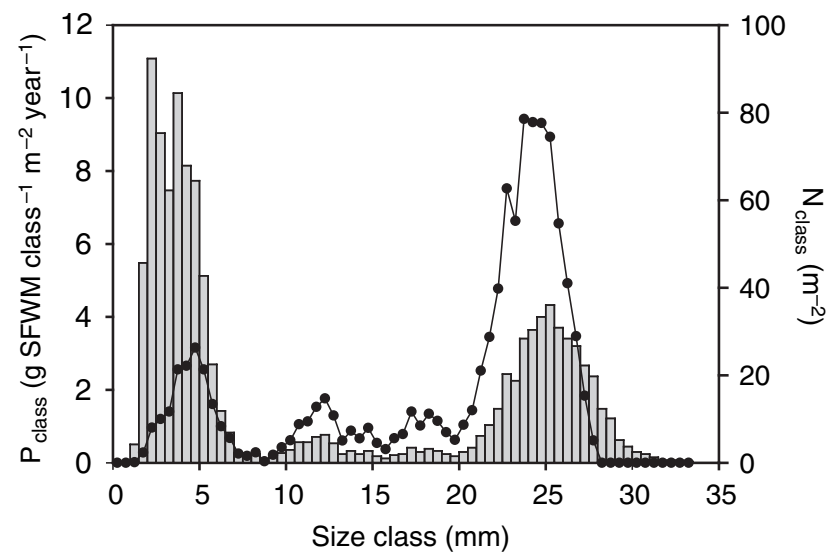

Fig. 5. Height-frequency distribution (bars, $\mathrm{N}$ class ${ }^{-1} \mathrm{~m}^{-2}$ ) and corresponding somatic production $P_{\text {class }}$ distribution (dots, g SFWM class ${ }^{-1} \mathrm{~m}^{-2}$ year ${ }^{-1}$ ) of Tawera gayi in Ushuaia Bay

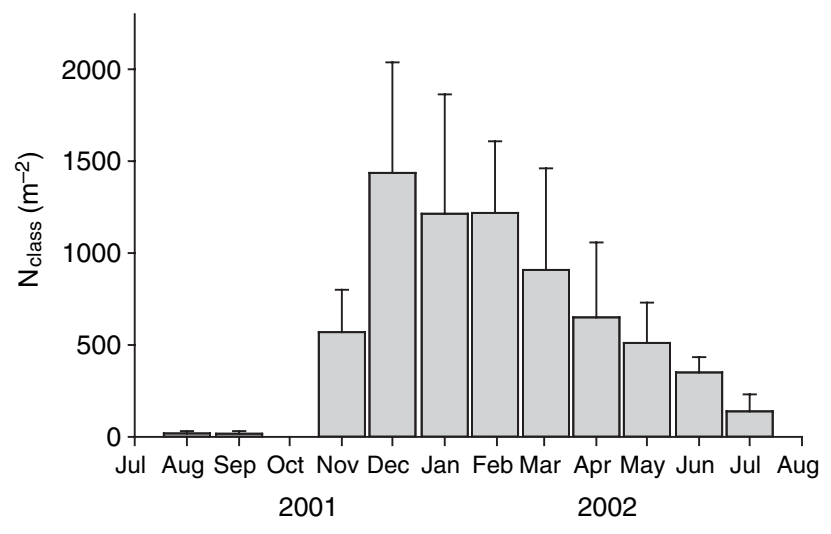

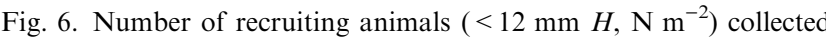
from monthly core samples between August 2001 and July 2002 


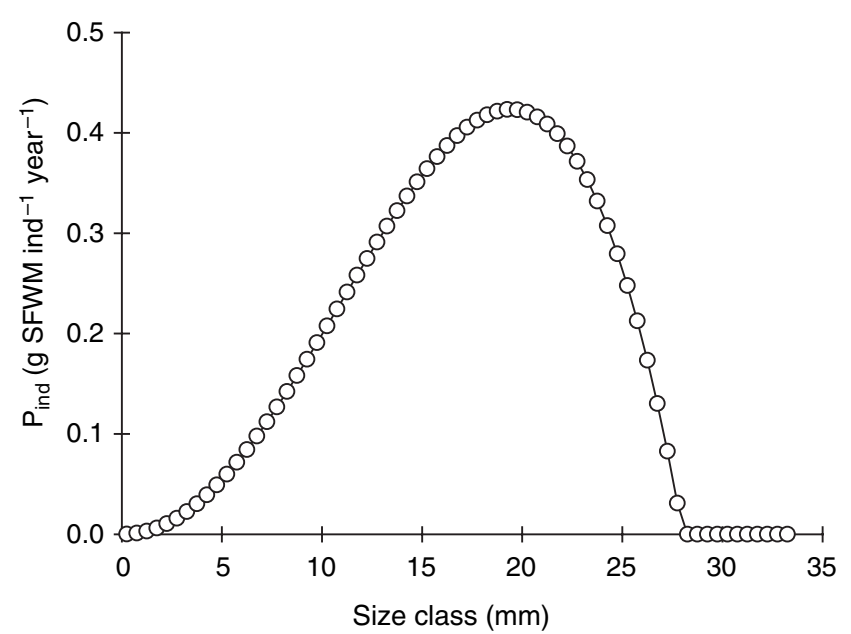

Fig. 7. Individual production of soft tissue (g SFWM ind. ${ }^{-1}$ year $^{-1}$ ) vs shell height in Tawera gayi. Values for $P_{\text {ind }}$ in size classes above $H_{\infty}=28.03$ were set to the value of $P_{\text {ind. }}$. of the size class $27.75 \mathrm{~mm}$

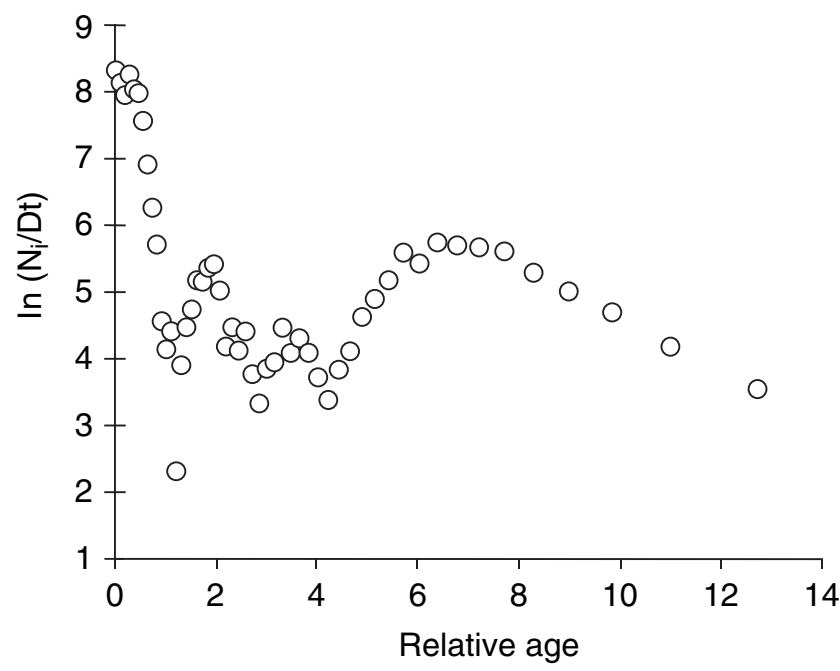

Fig. 8. Size-converted catch curve of Tawera gayi based on the overall size-frequency distribution and the von Bertalanffy growth function parameters. The curve shown no \pm continuously descending right arm, i.e. the single negative exponential model does not fit the data

the whole population cannot be computed. The taggingrecapture data -18 of 18 recovered dead clams drilled by snails - indicate that predation by gastropods is a major source of mortality.

\section{Discussion}

The shell growth pattern of $T$. gayi in Ushuaia Bay alternating narrow translucent and broad opaque bands (Fig. 3) - resemble growth patterns observed in other species of the genus Tawera (Luckens, 1990, 1991; Isla and Gordillo, 1996) as well as in other venerid bivalves such as Eurhomalea exalbida (Lomovasky et al., 2002a,b), Mercenaria campichiensis (Jones et al., 1990; Arnold et al., 1996, 1998), M. mercenaria (Jones et al., 1990; Arnold et al., 1991, 1996, 1998) and Venus verrucosa (Arneri et al., 1998).

The presence of growth rings indicates periods of very slow or even halted shell growth (Rhoads and Lutz, 1980) possibly caused by either (i) low metabolic rates related to low environmental temperatures (Grizzle and Lutz, 1988; Jones et al., 1990; Lomovasky et al., 2002a); (ii) a lack of food (Green, 1973; Beukema and Desprez, 1986; Beukema and Cadée, 1991; Kube et al., 1996; Arneri et al., 1998); or by (iii) a diversion of metabolic products away from shell growth into gamete production (Morton, 1978; Ankar, 1980; Peterson and Fegley, 1986; Ramón et al., 1995; Arneri et al., 1998; Lomovasky et al., 2002a). In T. gayi, the translucent bands corresponding to slow or halted growth are formed in autumn/ winter, i. e. temperature (Fig. 2) and/or food availability are most likely to affect shell growth.

The growth parameters values of the von Bertalanffy function were estimated to be $H_{\infty}=28.03 \mathrm{~mm}\left(L_{\infty}=\right.$ $34.30 \mathrm{~mm}$; see Table 1 for conversion), $K=0.288$ and $t_{0}=-0.34$ (Fig. 4). Urban and Tesch (1996) determined distinctly different parameter values for $T$. gayi from Laredo Bay $\left(52^{\circ} 58^{\prime} \mathrm{S}\right)$, Magellan Strait, $L_{\infty}=21.7 \mathrm{~mm}, K=0.462$ and $t_{0}=-0.13$. These values, however, are most likely affected by biased sampling, as Urban and Tesch (1996) collected a 'qualitative' sample that only contained animals $<21 \mathrm{~mm}$ shell height and that were under 5 years of age.

Tawera gayi from Ushuaia Bay $\left(54^{\circ} 50^{\prime} \mathrm{S}\right.$; this paper) can reach a maximum age of 15 years, similar to T. mawsoni from Macquarie Island $\left(54^{\circ} 29^{\prime}-55^{\circ} 01^{\prime} \mathrm{S}\right)$, New Zealand (Luckens, 1990). Other maximum age estimates for T. gayi appear to be unreliable owing to non-representative sampling as well as non-validated ageing methods (Isla and Gordillo, 1996; Urban and Tesch, 1996).

The annual somatic production of T. gayi was $120.45 \mathrm{~g}$ SFWM m ${ }^{-2}$ year $^{-1}\left(=456.51 \mathrm{~kJ}\right.$; converted by $3.79 \mathrm{~kJ} \mathrm{~g}^{-1}$ SFWM; Brey, 1999) with a mean biomass of $901.83 \mathrm{~g} \mathrm{~m}^{-2}$ (=3417.94 $\mathrm{kJ} \mathrm{m}^{-2}$ ), corresponding to a $P / B$ ratio of 0.134 year $^{-1}$. This value is as low as the $P / B$ ratio reported for a sympatric population of another venerid, E. exalbida, 0.119 year $^{-1}$ (Lomovasky et al., 2002a) and is among the lowest ever reported for venerid populations such as Anomalocardia brasiliana (Monti et al., 1991), Callista brevisiphonata (Selin and Selina, 1988), Chamelea gallina (Ramón and Richardson, 1992), Chione cancellata (Moore and Lopez, 1969), Dosinia hepatica (Hanekom, 1986), M. mercenaria (Hibbert, 1976, 1977a,b; Walker and Tenore, 1984), Tapes philippimarum (Yap, 1977), Venerupis decussata (Guelorget et al., 1980), V. aurea (Hibbert, 1976; Guelorget et al., 1980), V. antiqua (Clasing et al., 1994), V. ovata (Dauvin, 1985) and $V$. striatula (Warwick et al., 1978).

Recruits (animals $<12 \mathrm{~mm}$ shell height, $<1$ year old) were present year-round (Fig. 6), with a major peak occurring in summer. The preliminary analysis of the reproductive cycle of T. gayi (E. Morriconi, pers. comm.) indicates that the observed recruitment pattern corresponds to the continuous presence of mature gonads throughout the year, with a major spawning event during November.

Mortality patterns within this population of $T$. gayi appear to be complex. Obviously, the single negative exponential mortality model does not apply and hence we cannot provide a population mortality estimate. The size-converted catch curve plot indicates, however, that mortality is quite high in small specimens and lower in larger specimens, which to some extent may be able to outgrow their predators. The dead shell assemblage along the coastline (about $95 \%$ of all shells with drill holes; pers. comm.) as well as our field experiment strongly indicate that gastropods such as Xymenopsis muriciformis, Trophon geversianus and Natica sp., are the major predators of $T$. gayi from Ushuaia Bay, a situation similar to the one observed in T. mawsoni from Macquarie Island, New 
Zealand (Luckens, 1990). Tawera gayi, as other species of the genus Tawera from Australasian (Luckens, 1990, 1991), are usually found close the sediment surface. Thus, they are easier prey for snails than are the deeper-dwelling venerids such as E. exalbida (Lomovasky et al., 2002a). These highly mobile predators, together with the comparatively slow growth and low turnover of T. gayi in Ushuaia Bay, limit its potential for sustainable commercial exploitation.

\section{Acknowledgements}

Authors thank Daniel Aureliano, Adalberto Ferlito and Marcelo Santos in Argentina for technical assistance, and the collaboration of Olaf Heilmayer and Kerstin Beyer from the Alfred Wegener Institute for Polar and Marine Research in Bremerhaven, Germany. This work was supported by the German-Argentinian Bilateral Cooperation Program in Science and Technology (BMBF and SECyT) (ARG 001/99 MAR-AL/A99-UXIII/12) and Fundación Antorchas (138174/2000).

\section{References}

Ankar, S., 1980: Growth and production of Macoma balthica (L.) in a northern Baltic soft bottom. Ophelia 1, 31-48.

Arneri, E.; Giannetti, G.; Antolini, B., 1998: Age determination and growth of Venus verrucosa L. (Bivalvia: Veneridae) in the southern Adriatic and the Aegean Sea. Fish. Res. 38, 193-198.

Arnold, W. S.; Marelli, D. C.; Bert, T. M.; Jones, D. S.; Quitmyer, I. R., 1991: Habitat-specific growth of hard clam Mercenaria mercenaria (L.) from the Indian River, Florida. J. Exp. Mar. Biol. Ecol. 147, 245-265.

Arnold, W. S.; Bert, T. M.; Marelli, D. C.; Cruz-Lopez, H.; Gill, P. A., 1996: Genotype-specific growth of hard clams (genus Mercenaria) in a hybrid zone: variation among habitats. Mar. Biol. 125, 129139

Arnold, W. S.; Bert, T. M.; Quitmyer, I. R.; Jones, D. S., 1998: Contemporaneous deposition of annual growth bands in Mercenaria mercenaria (Linnaeus), Mercenaria campechiensis (Gmelin), and their natural hybrid forms. J. Exp. Mar. Biol. Ecol. 223, 93109

Beukema, J. J.; Cadée, G. C., 1991: Growth rate of the bivalve Macoma balthica in the Wadden Sea during a period of eutrophication: relationships with concentrations of pelagic diatoms and flagellates. Mar. Ecol. Prog. Ser. 68, 249-256.

Beukema, J. J.; Desprez, M., 1986: Single and dual annual growing seasons in the tellind bivalve Macoma balthica (L.). J. Exp. Mar. Biol. Ecol. 102, 35-45.

Brey, T., 1999: Growth performance and mortality in aquatic benthic invertebrates. Adv. Mar. Biol. 35, 153-223.

Brey, T., 2001: Population dynamics in benthic invertebrates. A virtual handbook: http://www.awi-bremerhaven.de/Benthic/Ecosystem/ FoodWeb/Handbook/main.html. Alfred Wegener Institute for Polar and Marine Research, Germany.

Carcelles, A., 1944: Catálogo de los moluscos marinos de Puerto Quequén. Rev. Museo La Plata, Secc. Zool. 3, 233-309.

Carcelles, A., 1950: Catálogo de los moluscos marinos de la Patagonia. Rev. Museo Arg. Cs. Nat. Bno. Riv. 2, 41-100.

Clasing, E.; Brey, T.; Stead, R.; Navarro, J.; Asencio, G., 1994: Population dynamics of Venus antiqua (Bivalvia: Veneracea) in the Bahía de Yaldad, Isla de Chiloé, southern Chile. J. Exp. Mar. Biol. Ecol. 177, 171-186.

Crisp, D. J., 1984: Energy flow measurements. In: Methods for the study of marine benthos. N. A. Holme and A. D. McIntyre (Eds). Blackwell, London, pp. 284-372.

Dauvin, J.-C., 1985: Dynamique et production d'une population de Venus ovata Pennant (Mollusque-Bivalve) de la baie de Morlaix (Manche occidentale). J. Exp. Mar. Biol. Ecol. 91, 109-123.

Dell, R. K., 1964: Antarctic and Subantarctic mollusca: Amphineura, Scaphopoda and Bivalvia. Discov. Rep. 33, 93-250.

Green, R. H., 1973: Growth and mortality in an Arctic intertidal population of Macoma balthica (Pelecypoda, Tellinidae). J. Fish. Res. Board Can. 30, 1345-1348.
Grizzle, R. E.; Lutz, R. A., 1988: Descriptions of macroscopic banding patterns in sectioned polished shells of Mercenaria mercenaria from southern New Jersey. J. Shellfish Res. 7, 367-370.

Guelorget, O.; Mayere, C.; Amanieu, M., 1980: Croissance, biomasse et production de Venerupis decussata et Venerupis aurea dans une lagune Méditerranée, l' etang du Prevost a Palavas (Herault, France). Vie Mar. 2, 25-38.

Hanekom, N., 1986: Growth and somatic production estimates of Dosinia hapatica (Lamark) (Mollusca: Bivalvia) in the Swartkops Estuary, South Africa. S. Afr. Tydskr. Dierk. 21, 325-330.

Hibbert, C. J., 1976: Biomass and production of a bivalve community on an intertidal mud-flat. J. Exp. Mar. Biol. Ecol. 25, 249-261.

Hibbert, C. J., 1977a: Energy relations of the bivalve Mercenaria mercenaria on an intertidal mudflat. Mar. Biol. 44, 77-84.

Hibbert, C. J., 1977b: Growth and survivorship in a tidal-flat population of the bivalve Mercenaria mercenaria from Southampton waters. Mar. Biol. 44, 71-76.

Isla, M. S.; Gordillo, S., 1996: Age and growth of the clam Tawera gayi (Hupé) from Golondrina Bay (Beagle Channel, Tierra del Fuego). Naturalia Patagónica 4, 33-40.

Jones, D. S.; Quitmyer, I. R.; Arnold, W. S.; Marelli, D. C., 1990: Annual shell banding, age, and growth rate of hard clams (Mercenaria spp.) from Florida. J. Shellfish Res. 9, 215-225.

Kube, J.; Peters, C.; Powilleit, M., 1996: Spatial variation in growth of Macoma balthica and Mya arenaria (Mollusca, Bivalvia) in relation to environmental gradients in the Pomeranian Bay (Southern Baltic Sea). Arch. Fish. Mar. Res. 44, 81-93.

Lomovasky, B. J.; Brey, T.; Morriconi, E.; Calvo, J., 2002a: Growth and production of the venerid bivalve Eurhomalea exalbida in the Beagle Channel, Tierra del Fuego. J. Sea Res. 48, 209-216.

Lomovasky, B. J.; Morriconi, E.; Brey, T.; Calvo, J., 2002b: Individual age and connective tissue lipofuscin in the hard clam Eurhomalea exalbida. J. Exp. Mar. Biol. Ecol. 276, 83-94.

Luckens, P. A., 1990: Distribution, size-frequency, and growth-ring analyses of Tawera mawsoni (Bivalvia: Veneridae) at Macquarie Island. N. Z. J. Mar. Freshw. Res. 24, 59-73.

Luckens, P. A., 1991: Distribution, growth rate, and death from octopod and gastropod predation of Tawera bollonsi (Bivalvia: Veneridae) at the Auckland Islands. N. Z. J. Mar. Freshw. Res. 25, 255-268.

Monti, D.; Frenkiel, L.; Moueza, M., 1991: Demography and growth of Anomalocardia brasiliana (Gmelin) (Bivalvia: Veneridae) in a mangrove in Guadeloupe (French West Indies). J. Moll. Stud. 57, $249-257$.

Moore, H. B.; Lopez, N. N., 1969: The ecology of Chione cancellata. Bull. Mar. Sci. 19, 131-148.

Morton, B., 1978: The population dynamics of Anomalocardia squamosa Lamarck (Bivalvia: Veneracea) in Hong Kong. J. Moll. Stud. 44, 135-144.

Osorio, C.; Cifuentes, J. A.; Fischer, S. M., 1979: Moluscos marinos de importancia económica en Chile. Biol. Pesq. Chile 11, 3-47.

Pauly, D., 1984a: Length-converted catch curves: a powerful tool for fisheries research in the tropics (Part II). Fishbyte 2, 17-19.

Pauly, D., 1984b: Length-converted catch curves: a powerful tool for fisheries research in the tropics (Part III). Fishbyte 2, 8-10.

Peterson, C. H.; Fegley, S. R., 1986: Seasonal allocation of resources to growth of shell, soma, and gonads in Mercenaria mercenaria. Biol. Bull. 171, 597-610.

Ramón, M.; Richardson, C. A., 1992: Age determination and shell growth of Chamelea gallina (Bivalvia: Veneridae) in the western Mediterranean. Mar. Ecol. Prog. Ser. 89, 15-23.

Ramón, M.; Abelló, P.; Richardson, C. A., 1995: Population structure and growth of Donax trunculus (Bivalvia: Donacidae) in the western Mediterranean. Mar. Biol. 121, 665-671.

Rhoads, D. C.; Lutz, R. A., 1980: Skeletal growth of aquatic organisms. Plenum Press, New York, $750 \mathrm{pp}$.

Schuldt, M., 1975: Consideraciones sobre la reproducción de los pelecípodos chiónidos en la Cholguera de Punta Loma, Golfo Nuevo, Chubut. Physics 88, 137-146.

Selin, N. I.; Selina, M. S., 1988: Production characteristics of the bivalve mollusc Callista brevisiphonata in Peter the Great Bay, Sea of Japan. Soviet J. Mar. Biol. 14, 219-223.

Soot-Ryen, T., 1959: Pelecypoda. Acta Univ. Lund. Avd. 2 55, 1-86.

Urban, J. H.; Tesch, C., 1996: Aspects of the population dynamics of six bivalve species from Southern Chile. Results of the 'Victor Hensen' cruise to the Magellan Strait and the Beagle Channel in October/November 1994. Arch. Fish. Mar. Res. 44, 243-256. 
Walker, R. L.; Tenore, K. R., 1984: The distribution and production of the hard clam, Mercenaria mercenaria, in Wassaw Sound, Georgia. Estuaries 7, 19-27.

Warwick, R. M.; George, C. L.; Davies, J. R., 1978: Annual macrofauna production in a Venus community. Estuarine Coast. Mar. Sci. 7, 215-241.

Yap, W. G., 1977: Population biology of the Japanese little-neck clam, Tapes philippinarum, in Kaneohe Bay, Oahu, Hawaiian Islands. Pac. Sci. 31, 223-244.
Author's address: Dr Betina J. Lomovasky, Ecología, Dpto. de Biología (FCEyN), Universidad Nacional de Mar del Plata. CC 573 Correo Central (B7600WAG) Mar del Plata, Bs. As., Argentina.

E-mail: lomovask@mdp.edu.ar 